\title{
Regeneration of in Vitro Shoot and Root Structure through Hormone Manipulation of Coconut (MATAG F2) Zygotic Embryos
}

\author{
A. R. Zuraida1*, Kumeran G. Sentoor ${ }^{2}$, N. Ahmad ${ }^{2}$, Farhanah M. S. Syahirah ${ }^{1}$, Nazreena 0. Ayu ${ }^{1}$ \\ ${ }^{1}$ Biotechnology \& Nanotechnology Research Centre, MARDI Headquarters, Persiaran MARDI-UPM, Serdang, Malaysia \\ ${ }^{2}$ Crop Science and Soil Science Research Centre, MARDI Hilir Perak, Perak, Malaysia \\ Email: *azuraida@mardi.gov.my
}

How to cite this paper: Zuraida, A.R., Sentoor, K.G., Ahmad, N., Syahirah, F.M.S. and Ayu, N.O. (2017) Regeneration of in Vitro Shoot and Root Structure through Hormone Manipulation of Coconut (MATAG F2) Zygotic Embryos. American Journal of Plant Sciences, 8, 340-348.

https://doi.org/10.4236/ajps.2017.83024

Received: January 4, 2017

Accepted: February 1, 2017

Published: February 4, 2017

Copyright $\odot 2017$ by authors and Scientific Research Publishing Inc. This work is licensed under the Creative Commons Attribution International License (CC BY 4.0).

http://creativecommons.org/licenses/by/4.0/

\begin{abstract}
Zygotic embryos tissues have found to be more responsive explants for clonal propagation of coconut. In the present study, the feasibility of using zygotic embryos explants for clonal propagation of a local coconut variety MATAG F2 was assessed. Callus was induced by incorporating of cytokinin and auxin into the medium. The sliced embryos explants were immersed in $1 \mathrm{M}$ maltose for 60 mins, then with $0.05 \mathrm{M}$ maltose for $1 \mathrm{~min}$ and followed by $0.01 \mathrm{M}$ maltose for 5 mins was the best for prevention of phenolic compounds excretion. The callus formation depended on the concentration of 2,4-D in the media and the best effect was observed with the high level (2,4-D and BAP) tested. Attempts at inducing multiple shoot from the zygotic embryos callus were unsuccessful. No multiple shoots was present; most of the callus became root structure.
\end{abstract}

\section{Keywords}

Hormone Manipulation, Plant Growth Regulator, MATAG Coconut, Zygotic Embryo, Callus Induction

\section{Introduction}

Coconut is a very important crop for millions of people in tropical countries. There are many varieties that describe for coconut trees, for example "talls", "dwarfs" or hybrids between them. Tall varieties often live for 70 years or more. Many varieties have local names and they refer to their main use or appearance. There is a close relationship between the health of the leaves and the number of coconuts. Taking good care of coconut trees and not removing too many leaves for other uses will normally result in more coconuts. Demand for coconuts has grown upwards to 500 percent in the last decade. This is because coconut-based 
derivatives, such as soaps, virgin coconut oil, coconut water and health products and which has been shown in demand, so that producers may not be able to keep up. According to APCC (the Asian and Pacific Coconut Community), many plantations across Asia are experiencing zero growth, and some are even ceasing production. Then most of the farmers switch their focus to oil palm production. To date, coconut suppliers are struggling to meet the increasing demands of the global economy. A continuity to be profitable ventures in the future, to ensure farms are sustainable enough to stand the tests of time and meet future demands therefore, increase the plantation is one of the strategies. Early intentions have been made to micropropagate coconut through different explants such as immature inflorescence [1], tender leaf [2], and immature zygotic embryo [3]. Callus form coconut endosperm initiated using modified medium with IAA and BAP [4]. According to Chan et al., [5] clones from embryos were likely to show many of the desired characteristics of the parent palms. The present study reports the progress of callus regeneration of local coconut varieties (MATAG F2) using zygotic embryos.

\section{Materials and Methods}

\subsection{Plant Material, Aseptic Culture and Browning Secretion}

The experiments of this study were carried out at Tissue Culture Research Laboratory, Biotechnology and Nanotechnology Research Central, Malaysia Agriculture Research \& Development Institute in order to investigate the response of the coconut (MATAG F2) zygotic embryos under the effect of different concentrations of cytokinin (BAP) and auxin (NAA, 2,4-D), and different segment of zygotic for callus induction and regeneration. A zygotic embryo (Figure 1(a)) was conducted in the laminar flow chamber to reduce the risk of contamination. The laminar flow was cleaned with $70 \%$ ethanol before commencing work. The zygotic embryos were removed from the seeds using the scalpel blades and forceps. Zygotic embryos of MATAG coconut were and sterilized by immersion in $50 \%$ ethanol for $2 \mathrm{~min}$, then in $1 \%$ Vircon for $30 \mathrm{~min}$. This was followed by further sterilization in Clorox (sodium hypochlorite, 5.2\%), first with the embryos immersed in 50\% Clorox for $40 \mathrm{~min}$, followed by immersion in 10\% Clorox for $20 \mathrm{~min}$. After rinsing three times in sterile distilled water, the embryos were cut into three segment and named as top, middle and bottom segment (Figure 1). The segments were immersed in maltose solution at different concentrations with three different times. The explants was immersed in $0.5 \mathrm{M}$ maltose for 30 mins and then treated with $0.05 \mathrm{M}$ maltose for $1 \mathrm{~min}$, followed by $0.01 \mathrm{M}$ maltose for 5 mins. The others treatment of immersion were listed in Table 1. After immersion, the segment then cultured on the specified media and incubated for one month at $26^{\circ} \mathrm{C} \pm 2{ }^{\circ} \mathrm{C}$ in dark. The cultured embryos were then observed and the percentage of browning recorded.

\subsection{Callus Induction and Regeneration}

The sterilized explants (top, middle and bottom segment) were immersed in $1 \mathrm{M}$ 
maltose for $60 \mathrm{mins}$ and then treated with $0.05 \mathrm{M}$ maltose for $1 \mathrm{~min}$, followed by $0.01 \mathrm{M}$ maltose for 5 mins. Then, the explants were placed in each $150 \mathrm{ml}$ flask containing $40 \mathrm{~mL}$ MS media and respective 2,4-D concentration 0, 1.0, 5.0, 10.0 and $20.0 \mathrm{mg} / \mathrm{L}$ combined with BAP (1.0 and $5.0 \mathrm{mg} / \mathrm{L})$ or NAA (1.0 and 5.0 $\mathrm{mg} / \mathrm{L}$ ) as listed in Table 2 for callus inintiation. The MS media added with $0.1 \mathrm{~g}$ arginine, 0.1 asparagine, $0.1 \mathrm{~g}$ glutamine, $3.0 \%$ sucrose, $0.3 \%$ gelrite agar for gelling. A total of 20 flasks containing 3 sliced zygotic embryos were used for each treatment and repeated twice. Medium sterilization was performed by autoclaving at $121^{\circ} \mathrm{C}$ for 15 mins. The medium $\mathrm{pH}$ was adjusted to 5.7 - 5.8 before adding agar. Visual growths of callus were recorded after 3 - 4 months in culture.

\subsection{Histological Analysis}

Zygotic embryos were fixed in a FAA solution for 12 - 24 hours, dehydrated through a series of ethanol solution and embedded in paraffin wax. The specimen were sectioned at $3-4 \mu \mathrm{m}$ and stained with $0.5 \%(\mathrm{w} / \mathrm{v})$ fast green and $0.25 \%(\mathrm{w} / \mathrm{v})$ safranin. The stained samples were observed under a light microscope equipped with a camera connecting to the computer system.

\subsection{Statistical Analysis}

All data were calculated by the mean of the twenty individual experiments. Each experiments were designed in CRD (Complete randomized design) which followed by two replicates. All mean data were analyzed by one way ANOVA via SPSS software version 20. Comparisons of the mean data and standard error (S.E) were determined by Turkey's multiple range tests at $\mathrm{P}<0.05$ level of significance.

\section{Results and Discussion}

\subsection{Influence of Maltose on Browning Secretion in Zygotic Embryos Culture}

Browning occurring in tissue culture of coconut zygotic embryos restrained the induction and growth of callus and the process of regeneration. In coconut tissue culture, explants browning and subsequent explants death was the first issue need to be overcome. Maltose has demonstrated that phenolic secretion problems reduced when it was added into immersion solution medium. The results showed that maltose can control browning obviously, in which treatment of $1 \mathrm{M}$, 0.05 and $0.01 \mathrm{M}$ of maltose for 60,1 , and $5 \mathrm{mins}$, respectively was optimal to prevent browning of explants. In addition, they showed only $20 \%$ of browning (Table 1). Application of maltose of $1 \mathrm{M}$ eliminated browning effectively compared to $0.5 \mathrm{M}$. Culturing of Primula vulgaris in half-strength MS with $0.1 \mathrm{M}$ maltose was limited in browning and callus induction observed [6]. Previous reports have also found maltose to be a better carbon source for regeneration, which supplementation of $4 \%$ maltose showed best results for per cent callus induction (90.33\%), embryogenic callus formation (57.66\%) and shoot regeneration (82.66\%) in Japonica Rice Cv. Kitaake [7]. In 1995, Lentini et al. [8] stated 
that maltose has been described as an agent that may regulate osmotic potential of cellular environment of callus. The use of sucrose might promotes in vitro production of ethylene in excised tissues causing the browning of callus, the substitution of maltose for sucrose could help to protect the calli by reducing the production of ethylene. Similar results that maltose is better sources of carbohydrate in both the subculture and differentiation media were obtained by Lin et al. [9].

\subsection{Callus Induction and Regeneration}

Three zygotic embryos segments (top, middle and bottom) (Figures 1(a)-(e)) were cultured on callus induction medium containing different plant growth regulators named 2,4-D, BAP and NAA. Histology analysis was done on the segment. Middle segment showed clear and more cambium, which this cambium are merestimatic cells (Figure 1(f)). The cell has potential to be dedifferentiated and become callus. Feher et al. [10] reported that meristematic cells have to be dedifferentiated and their cell division cycle has to be activated during

Table 1. Effect of maltose at different concentration and immersion time on phenolic secretion (percentage of browning) in sliced embryos explants. Explants cultured on MS medium supplemented with different maltose $(0.01-1.0 \mathrm{M})$. Data were collected after 4 weeks of culture.

\begin{tabular}{|c|c|c|c|}
\hline First immerse & Second Immerse & Third immerse & Percentage of Browning (\%) \\
\hline Maltose $0.5 \mathrm{M}$ & Maltose $0.05 \mathrm{M}$ & Maltose $0.01 \mathrm{M}$ & \\
\hline 30 & 1 & 5 & 80 \\
\hline 30 & 10 & 5 & 70 \\
\hline 30 & 20 & 5 & 70 \\
\hline 45 & 1 & 5 & 60 \\
\hline 45 & 10 & 5 & 60 \\
\hline 45 & 20 & 5 & 60 \\
\hline 60 & 1 & 5 & 70 \\
\hline 60 & 10 & 5 & 50 \\
\hline 60 & 20 & 5 & 50 \\
\hline Maltose $1.0 \mathrm{M}$ & Maltose $0.05 \mathrm{M}$ & Maltose $0.01 \mathrm{M}$ & \\
\hline 30 & 1 & 5 & 40 \\
\hline 30 & 10 & 5 & 40 \\
\hline 30 & 20 & 5 & 40 \\
\hline 45 & 1 & 5 & 30 \\
\hline 45 & 10 & 5 & 30 \\
\hline 45 & 20 & 5 & 30 \\
\hline 60 & 1 & 5 & 20 \\
\hline 60 & 10 & 5 & 30 \\
\hline 60 & 20 & 5 & 30 \\
\hline
\end{tabular}



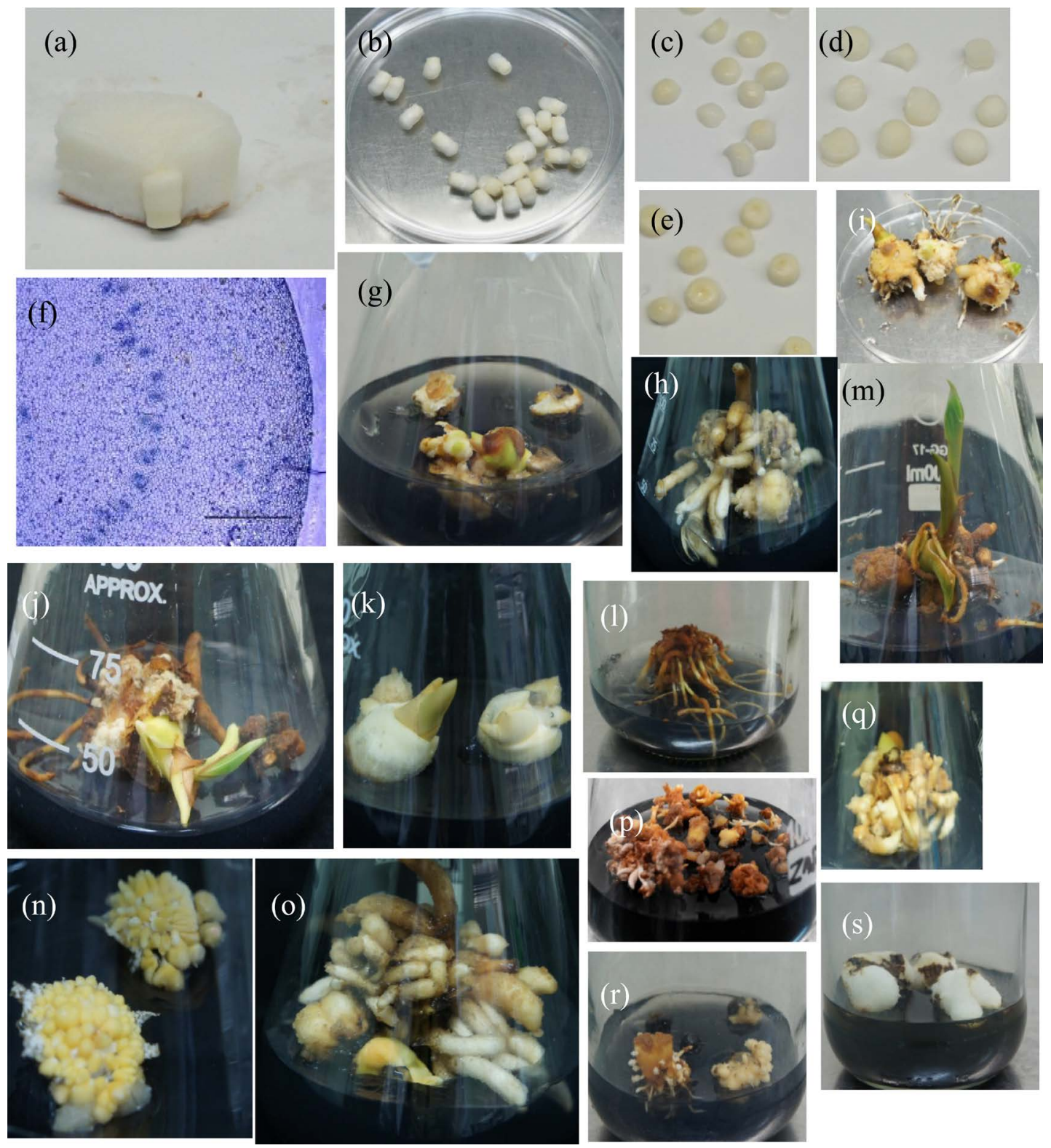

Figure 1. Callus initiation and regeneration from zygotic embryos of MATAG F2 coconut. Whole zygotic embryos ((a), (b)), (c) top zygotic embryos, (d) middle zygotic embryos, (e) bottom zygotic embryos, (f) histological observation of zygotic emryos at middle segment, $((\mathrm{g})-(\mathrm{m}))$ callus, roots and shoots from top segment of embryos, ((n)-(r)) callus and roots structure from middle segment of embyos, (s) cork callus from bottom segment of embryos. Bar in $\mathrm{f}=0.5 \mathrm{~mm}$.

the transition. Similar clarification were also reported in other monocot species of Curcuma longa [11], Cocus nucifera [12], Phoenix dactylifera [13] and Elaeis guineensis [14].

Among different plant growth regulators tested, optimum callus was observed on MS medium supplemented with 2,4-D (20 mg/L) combine with BAP (5 $\mathrm{mg} / \mathrm{L}$ ) (Table 2) after 3 - 4 months in culture. Middle segment showed better response in callus induction compared to other part. A decrease in callus induction was observed when 2,4-D was used in combination with different concentrations of NAA. Callus induction was found to increase with increase in the 
concentration of 2,4-D. Finding by Tahir et al. [15], indicated that percentage of callus formation by adding 2,4-D at $4.0 \mathrm{~g} / \mathrm{L}$ gave the best result followed by 3.5 $\mathrm{mg} / \mathrm{L}$ in Saccharum officinarum. As Yusnita and Dwi Hapsoro [16] had done with oil palm using a combination of $100 \mathrm{mg} / \mathrm{L}$ 2,4-D with activated charcoal led to higher percentage of callus induction after 7 months of incubation. In addition, the treatment of 2,4-D alone at $3.3 \mathrm{mg} / \mathrm{L}$ also resulted in the highest percentage of callus induction.

After within 7 months, with subculture interval of two months, all bottom segment become single shoot where treatment of $20 \mathrm{mg} / \mathrm{l}$ 2,4-D and $1 \mathrm{mg} / \mathrm{l} \mathrm{BAP}$ showed highest in number of shoot at average 1.2\# (Figures $1(\mathrm{~m})-(\mathrm{k})$ ). Similar result was observed for the middle segment, 0.8 averages of shoots produced when cultured on this medium. The frequency of root response was greatly influenced by type of segment with plant growth regulator concentration and the best results achieved at $20 \mathrm{~g} / \mathrm{L} 2,4-\mathrm{D}$ and $1 \mathrm{~g} / \mathrm{L}$ of BAP supplemented. The maximum number of roots was recorded at 21 \# from the middle segment. More roots generated after sub-cultured and placed into light condition (Figure 1(q), Figure 1(o)). Middle segment is the best for callus induction and regeneration

Table 2. Effect of different concentrations and combinations of 2,4-D, BAP and NAA on growth of callus from different segment of embryos (top, middle and bottom segment) that cultured within $3-4$ moths.

\begin{tabular}{|c|c|c|c|c|}
\hline \multicolumn{2}{|c|}{ Treatments (mg/L) } & \multicolumn{3}{|c|}{ Visual growth of callus after 3-4 months in culture } \\
\hline $2,4-\mathrm{D}$ & BAP & Top segment & Middle & Bottom \\
\hline 0 & 0 & - & - & - \\
\hline 1 & 1 & - & - & - \\
\hline 1 & 5 & - & - & - \\
\hline 5 & 1 & - & + & + \\
\hline 5 & 5 & - & + & + \\
\hline 10 & 1 & ++ & + & + \\
\hline 10 & 5 & ++ & ++ & + \\
\hline 20 & 1 & ++ & +++ & ++ \\
\hline 20 & 5 & ++ & +++ & +++ \\
\hline $2,4-\mathrm{D}$ & NAA & & & \\
\hline 1 & 1 & - & - & - \\
\hline 1 & 5 & - & + & + \\
\hline 5 & 1 & - & + & + \\
\hline 5 & 5 & - & + & + \\
\hline 10 & 1 & - & + & + \\
\hline 10 & 5 & + & ++ & ++ \\
\hline 20 & 1 & + & + & + \\
\hline 20 & 5 & - & + & + \\
\hline
\end{tabular}

*- No callus, + growth almost retarded, ++ slow growth and browning, ++ Poor callus, +++ Moderate callus. Data represent means of ten replicates. 
become root segment and there was some root turned browning However, only single shoot observe for this treatment. No shoot obtained from the top segment of embryos and most of them became cork-like structure (Figure 1(r)).

\section{Conclusion}

The results of this study indicated the possibility of callus inducing of the local variety coconut (MATAG F2) using zygotic embryos explants. The concentration of 2,4-D in the callusing medium was found to be the critical factor determining success in callogenesis. Most favorable callus was observed on MS medium supplemented with $20 \mathrm{mg} / \mathrm{L}$ 2,4-D and $5 \mathrm{mg} / \mathrm{L}$ BAP which middle segment showed the best response in callus induction. Varying the levels of growth regulator 2,4-D (Table 3) and BAP did not show any positive response on the regeneration and multiplication of shoots. No multiple shoots was observed and

Table 3. Effects of different concentrations of 2, 4-D and BAP on regeneration from embryos and callus.

\begin{tabular}{|c|c|c|c|c|c|}
\hline \multicolumn{2}{|c|}{ Treatments $(\mathrm{mg} / \mathrm{L})$} & \multicolumn{3}{|c|}{ Regeneration } & \multirow[b]{2}{*}{$\begin{array}{l}\text { Colour and texture } \\
\text { (roots \& shoots) }\end{array}$} \\
\hline $2,4-\mathrm{D}$ & BAP & $\begin{array}{l}\text { Shoots } \\
\text { average }\end{array}$ & $\begin{array}{l}{ }^{*} \text { Rooting } \\
\text { response } \\
(\%)\end{array}$ & $\begin{array}{c}\text { Average } \\
\text { number } \\
\text { of root }\end{array}$ & \\
\hline \multicolumn{6}{|c|}{ Top segment } \\
\hline 10 & 0 & 0 & - & 0 & No roots \& shoots \\
\hline 10 & 1 & 0 & - & 0 & No roots \& shoots \\
\hline 10 & 3 & 0 & - & 0 & No roots \& shoots \\
\hline 20 & 0 & 0 & - & 0 & No roots \& shoots \\
\hline 20 & 1 & 0 & - & 0 & No roots \& shoots \\
\hline 20 & 3 & 0 & + & $3+0.9$ & Root browning \\
\hline \multicolumn{6}{|c|}{$\underline{\text { Middle segment }}$} \\
\hline 10 & 0 & 0 & +++ & $11+2.0$ & Roots white \& brown \\
\hline 10 & 1 & 0 & +++ & $17+3.0$ & Roots white \& brown \\
\hline 10 & 3 & 0 & +++ & $18+4.3$ & Roots white \& brown \\
\hline 20 & 0 & 0 & +++ & $9+2.0$ & Roots white \\
\hline 20 & 1 & $0.2+0.01$ & +++ & $21+3.1$ & Single shoots with roots \\
\hline 20 & 3 & $0.8+0.01$ & +++ & $18+3.3$ & Single shoots with roots \\
\hline \multicolumn{6}{|c|}{$\underline{\text { Bottom segment }}$} \\
\hline 10 & 0 & 0.8 & + & 0 & Single shoots \\
\hline 10 & 1 & 0.8 & ++ & 5 & Single shoots with roots \\
\hline 10 & 3 & 1 & ++ & 2 & Single shoots with roots \\
\hline 20 & 0 & 0.6 & ++ & 1 & Single shoots with roots \\
\hline 20 & 1 & 1.2 & + & 3 & Two shoots with roots \\
\hline 20 & 3 & 1 & + & 3 & Single shoots with roots \\
\hline
\end{tabular}

*root response: - no growth; + slow growth; ++ moderate growth; +++ healthy \& fast growth. 
callus turned to root structure. Callus induction of the current protocol should be further improved for mass scale propagation of coconut using zygotic embryos explants.

\section{Acknowledgements}

The authors would like to thank to MARDI for supporting this research work under RMK11-coconut grant.

\section{References}

[1] Malik, A.S., Boyko, O., Atkar, N. and Young, W.F. (2001) A Comparative Study of MR Imaging Profile of Titanium Pedicle Screws. Acta Radiologica, 42, 291-293. https://doi.org/10.1080/028418501127346846

[2] Branton, R.L. and Blake, J. (1983) Development of Organized Structures in Callus Derived from Explants of Cocos nucifera L. Annals of Botany, 52, 673-678.

[3] Raju, C.R., Prakash, K.P., Chandramohan, M. and Iyer, R.D. (1984) Coconut Plantlets from Leaf Tissue Cultures. Plantation Crops, 12, 5-81.

[4] Karunaratne, S. and Periyapperuma, K. (1989) Culture of Immature Embryos of Coconut, Coconut, Cocos nucifera L.: Callus Proliferation and Somatic Embryogenesis. Plant Science, 62, 247-253. https://doi.org/10.1016/0168-9452(89)90087-3

[5] Olivia, C., Agaton, Evelyn, M.T.M. and Dolores, A. (1989) Ramirez. Induction of Callus from Endosperm. Philipp Journal Crop Science, 14, 127-132.

[6] Chan, J.L., Saenz, L., Talavera, C., Hornung, R., Robert, M. and Oropeza, C. (1998) Regeneration of Coconut (Cocos nucifera L.) from Plumule Explants through Somatic Embryogenesis. Plant Cell Reports, 17, 515-521. https://doi.org/10.1007/s002990050434

[7] Sadiye, H., Mark, A., Smedley, Jinhong, L., Wendy, A.H. and Philip, M. (2016) Gilmartin. Plant Regeneration from Leaf-Derived Callus Cultures of Primrose (Primula vulgaris). Hortscience, 51, 558-562.

[8] Saroj, K.S., Ajinder, K. and Jagdeep, S.S. (2014) High Frequency Embryogenic Callus Induction and Whole Plant Regeneration in Japonica Rice Cv. Kitaake. Journal Rice Research, 2, 1-5.

[9] Lentini, Z., Reyes, P., Marinez, C.P. and Roca, W.M. (1995) Androgenesis of Highly Recalcitrant Rice Genotypes with Maltose and Silver Nitrate. Plant Science, 110, 127-138. https://doi.org/10.1016/0168-9452(95)04180-3

[10] Lin, Y.J. and Zhang, Q. (2005) Optimising the Tissue Culture Conditions for High Efficiency Transformation of Indica Rice. Plant Cell Reports, 23, 540-547. https://doi.org/10.1007/s00299-004-0843-6

[11] Feher, A., Pasternak, T.P. and Dudits, D. (2003) Transition of Somatic Cells to an Embryogenic State. Plant Cell Tissue and Organ Culture, 74, 201-228. https://doi.org/10.1023/A:1024033216561

[12] Raju, C.S., Aslam, A. and Shajahan, A. (2015) High-Efficiency Direct Somatic Embryogenesis and Plant Regeneration from Leaf Base Explants of Turmeric (Curcuma longa L.). Plant Cell Tissue and Organ Culture, 122, 79-87. https://doi.org/10.1007/s11240-015-0751-1

[13] Buffard-Morel, J., Verdeil, J.L. and Pannetier, C. (1992) Embryogenese Somatique du Cocotier (Cocos nucifera L.) a Partir D'explants Foliaires: Etudes Histologiques. Canadian Journal of Botany, 70, 735-741. https://doi.org/10.1139/b92-094

[14] Sané, D., Aberlenc, B.F., Gassama, D.Y.K., Sagna, M., Trouslot, M.F., Duval, Y. and 
Borgel, A. (2006) Histological Analysis of Callogenesis and Somatic Embryogenesis from Cell Suspensions of Date Palm (Phoenix dactylifera). Annals of Botany, 98, 301-308. https://doi.org/10.1093/aob/mcl104

[15] Schwandiman, J., Pannetier, C. and Michaux, N.F. (1988) Histology of Somatic Embryogenesis from Leaf Explants of the Oil Palm Elaeis guineensis. Annals of Bo$\operatorname{tany}, 62,43-52$.

[16] Tahir, M., Victor, K. and Abdulkadir, S. (2011) The Effect of 2, 4-Dichlorophenoxy Acetic Acid (2, 4-D) Concentration on Callus Induction in Sugarcane (Saccharum officinarum). Nigerian Journal of Basic and Applied Science, 19, 213-217.

Submit or recommend next manuscript to SCIRP and we will provide best service for you:

Accepting pre-submission inquiries through Email, Facebook, LinkedIn, Twitter, etc. A wide selection of journals (inclusive of 9 subjects, more than 200 journals) Providing 24-hour high-quality service User-friendly online submission system Fair and swift peer-review system Efficient typesetting and proofreading procedure Display of the result of downloads and visits, as well as the number of cited articles Maximum dissemination of your research work

Submit your manuscript at: http://papersubmission.scirp.org/ Orcontact ajps@scirp.org 